\title{
HAMBURG UNIVERSITY RADIOCARBON DATES I
}

\section{H W SCHARPENSEEL, F PIETIG, and H SCHIFFMANN}

Institut für Bodenkunde der Universität Bonn and Ordinariat für Bodenkunde der Universität Hamburg

Radiocarbon measurements are carried out mainly on soil samples and soil organic matter fractions. Benzene samples are prepared as described earlier (Scharpenseel and Pietig, 1969; 1970). Radioactivity is measured in a single quartz vial, using a Packard Tri Carb Model 3075 as well as a Berthold Betascint BF 5000. Most equipment has been transferred from Bonn University Radiocarbon Dating Lab to Hamburg, where operation of former Bonn Radiocarbon Lab will be continued.

\section{ACKNOWLEDGMENT}

Much of the technical work for sample preparation was carried out by E Kruse, M Fricke, and E Schneider. This work was supported by the German Federal Department of Research and Technology.

\section{SAMPLE DESCRIPTIONS}

\section{SOIL SAMPLES}

Pretreatment of soil samples is described elsewhere (Scharpenseel and Pietig, 1969; Scharpenseel, 1972).

\section{A. Germany}

Humus horizons in high flood loam, Hapludalf, on nether (lowest terrace level) terrace of Rhine R, Friesdorf, from large construction pit of Fed Dept Econ Coop ( $\left.50^{\circ} 43^{\prime} \mathrm{N}, 7^{\circ} 8^{\prime} \mathrm{E}\right)$.

\section{HAM-1.}

$5010 \pm 280$ 3060 вс depth.

Bt horizon in Hapludalf, near boundary of terrace gravel, $120 \mathrm{~cm}$

HAM-2.

$3620 \pm 70$ $1670 \mathrm{BC}$

Bt horizon in Hapludalf, $S$ side of pit, $80 \mathrm{~cm}$ depth. Samples coll and subm 1974 by H W Scharpenseel. Comment: dates do not measure up to fA horizon adjacent to terrace gravel $10 \mathrm{~km}$ farther N (BONN-1653: R, 1973, v 15, p 264). HAM-1 equals BN-1652 in Hersel pit. HAM-2 at $80 \mathrm{~cm}$ depth seems to be already in root zone and rejuvenated.

Samples of various horizons from soil formations in alluvial loess,

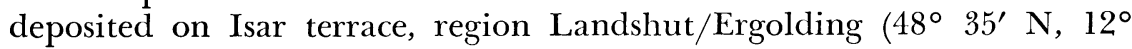
$11^{\prime} \mathrm{E}$ ). Different genetic soil types close together in catenary relation.

HAM-4. Aquept, loessic parent material, slightly colluvial cover, nether (lowest terrace level)

$1070 \pm 60$ terrace of Isar R, SW Altheim $4.5 \%$ C, AD 880 Ah 20 to $40 \mathrm{~cm}$. 
HAM- $5 . \quad 0.3 \%$ C, AGo 55 to $70 \mathrm{~cm}$

$5700 \pm 80$ 3750 BC

HAM-6. $1.1 \%$ C, AGroGr 70 to $85 \mathrm{~cm}$

$8420 \pm 100$ $6470 \mathrm{BC}$

HAM-7. $0.6 \%$ C, AGr 85 to $100 \mathrm{~cm}$

$10,880 \pm 140$ 8930 BC

HAM-8. Udoll on high terrace of Isar R, $1.3 \% \mathrm{C}$, Ah 20 to $45 \mathrm{~cm}$

$3180 \pm 80$ $1230 \mathrm{BC}$

HAM-9. $0.6 \% \quad$ C, $\mathrm{C}_{\mathrm{ca}} \mathrm{A} 45$ to $65 \mathrm{~cm}$

$3190 \pm 80$ $1240 \mathrm{BC}$

HAM- $10 . \quad 0.3 \%$ C, AC 65 to $75 \mathrm{~cm}$ $3050 \pm 80$ $1100 \mathrm{BC}$

HAM-11. Hapludalf on high terrace of Isar $\mathbf{R}$ (higher than Udoll, above), $0.9 \% \mathrm{C}$, Btl 40 to $60 \mathrm{~cm}$.

$2780 \pm 70$ $830 \mathrm{BC}$

HAM-12. $0.3 \%$ C, Bt2 60 to $75 \mathrm{~cm}$

$3320 \pm 70$ 1370 BC

HAM-13. $0.2 \%$ C, Bt 75 to $90 \mathrm{~cm}$ $2750 \pm 70$ 800 BC

HAM-14. Koislhof, transition between lower and upper nether (lowest terrace level) terrace of $3920 \pm 80$ Isar $\mathrm{R}$, colluvial vertic soil with $>60 \%$ clay, overlying nether moor $22.5 \% \mathrm{C}$, I Bt 30 to $50 \mathrm{~cm}$.

HAM-15. $38.0 \%$ C, II Hnl 50 to $70 \mathrm{~cm}$

$6540 \pm 120$

$4590 \mathrm{BC}$

HAM-16. $38.0 \%$ C, II $\mathrm{Hn} 270$ to $90 \mathrm{~cm}$

$8520 \pm 120$

6570 вС

HAM-17. $46.0 \%$ C, II Hn3 90 to $105 \mathrm{~cm}$

$9330 \pm 120$

7380 BC

HAM-18. $43.0 \%$ C, II $\mathrm{Hn} 4105$ to $130 \mathrm{~cm}$

$9490 \pm 100$

7540 вс

HAM-19. 21.4\% C, II Hn5 130 to $150 \mathrm{~cm}$

$10,250 \pm 130$ $8300 \mathrm{BC}$

HAM-20. 27.0\% C, II Hn6 150 to $170 \mathrm{~cm}$

$10,680 \pm 140$ $8730 \mathrm{BC}$

HAM-21. $8.3 \%$ C, III HnC 170 to $180 \mathrm{~cm}$

$10,600 \pm 140$ 8650 BC 
HAM-22. Deeply humic Hapludalf, Marktschwaben, $2.3 \% \mathrm{C}, \mathrm{AhSwdl} 25$ to $40 \mathrm{~cm}$.

$4650 \pm 90$ $2700 \mathrm{BC}$

$5260 \pm 80$

HAM-23. $1.2 \%$ C, AhSwd2 40 to $55 \mathrm{~cm}$ 3310 BC

HAM-24. $2.0 \% \mathrm{C}, \mathrm{Sd} 55$ to $75 \mathrm{~cm}$

$5790 \pm 120$ 3840 вС

HAM-25. Crotovine in Sd horizon, $55 \mathrm{~cm}$ $3820 \pm 80$ $1870 \mathrm{BC}$

Samples coll and subm 1974 by $\mathrm{H}$ W Scharpenseel and B Hofmann from Bayrisches Geol Landesamt, Munich. Comment: Aquept, HAM-4-7 dates to Alleröd origin; Udoll, HAM-8-10 as well as Hapludalf, HAM-1113 are of almost uniform age throughout profile, evidently rejuvenated by root growth and animal transport; deeply humic Hapludalf, HAM-22-25 arrive at $5800 \mathrm{yr}$ old, approx maximum, that recent Holocene soils with intact biodynamics will show. The Koislhof profile, HAM-14-21 with underlying low moor was expected to date to Atlantic. Dates indicate at least Alleröd age. For regional survey, see soil map 1:25000 Landshut Ost (Hofmann, 1966.)

Profiles with fossil horizons in N Bavarian landscape, S Danube.

HAM-26. Deeply humic colluvium upon old Riss moraine, $\quad 800 \pm 60$ $1 \mathrm{~km}$ N of Landsberg $\left(48^{\circ} 3^{\prime} \mathrm{N}, 10^{\circ} 53^{\prime} \mathrm{E}\right), \quad$ AD 1050 $0.5 \%$ C, Ap 15 to $30 \mathrm{~cm}$.

HAM-27. $\quad 0.5 \% \mathrm{C}, \mathrm{I} \mathrm{AB} 30$ to $60 \mathrm{~cm}$

$$
1240 \pm 70
$$
AD 710

HAM-28. $0.6 \%$ C, II Bvtl 60 to $90 \mathrm{~cm}$ $2080 \pm 70$ 130 BC

$3080 \pm 70$

HAM-29. $0.7 \%$ C, II Bvt21 90 to $140 \mathrm{~cm}$ $1130 \mathrm{BC}$

HAM-30. $1.0 \%$ C, II Bvt22 140 to $150 \mathrm{~cm}$ $4010 \pm 80$ 2060 BC

HAM-31. $0.7 \%$ C, III BvtCv 150 to $170 \mathrm{~cm}$ $4340 \pm 70$ $2390 \mathrm{BC}$

Samples coll and subm 1974 by $\mathrm{H}$ W Scharpenseel and H Grottenthaler, Bayrisches Geol Landesamt, Munich. Comment: "Ackerbrown earth", developed in loamy cover overlying old Riss moraine with humic colluvial patches in slight depressions is thought to be product of top soil material eroded during Germanic land occupation and deforestation. Considering time required for deposition of erosion product, dates fit well into theory. 
HAM-32. Chernozem like Mollisol in loess in steep bank of Lech R, Kaufering $\left(48^{\circ} 5^{\prime} \mathrm{N}, 10^{\circ}\right.$ $\left.53^{\prime} \mathrm{O}\right), 0.8 \%$ C, IAhl 0 to $30 \mathrm{~cm}$.

AD 1190

$$
760 \pm 70
$$

HAM-33. $0.7 \%$ C, I Ah2 30 to $65 \mathrm{~cm}$

$$
1160 \pm 70
$$

AD 790

$2140 \pm 70$

$190 \mathrm{BC}$

HAM-36. $\quad 0.3 \%$ C, IIfBt 95 to $110 \mathrm{~cm}$

$4410 \pm 80$

$2460 \mathrm{BC}$

Samples coll and subm 1974 by $\mathrm{H}$ W Scharpenseel and $\mathrm{H}$ Grottenthaler. Comment: in survey study of soils on Lech terraces, Diez (1968) estimates formation of Kaufering soil on main nether terrace at early Holocene. Maximum age of $4410 \mathrm{yr}$ falls short of expectation due to rejuvenation by root growth and animal transport.

HAM-37. Neuenried near sources of Mindel R, horizons of fossil organic matter in $1640 \pm 70$ tuffaceous limestone on top of AD 310 tertiary sand and marl $\left(47^{\circ} 54^{\prime} \mathrm{N}\right.$, $\left.10^{\circ} 27^{\prime} \mathrm{E}\right), 2.7 \% \mathrm{C}$, fAl 60 to $90 \mathrm{~cm}$.

HAM- $39.1 .2 \%$ C, fA2 105 to $115 \mathrm{~cm}$

$1070 \pm 70$ AD 880

HAM-40. $0.7 \%$ C, fA3 119 to $135 \mathrm{~cm}$

$1880 \pm 70$ AD 70

HAM-41. $1.1 \%$ C, fA4 137 to $145 \mathrm{~cm}$ $2460 \pm 70$ $510 \mathrm{BC}$

HAM-42. $0.7 \%$ C, fA5 165 to $190 \mathrm{~cm}$ $2560 \pm 80$ $610 \mathrm{BC}$

HAM-43. $10.2 \%$ C, fA6 315 to $320 \mathrm{~cm}$ (lignite + charcoal)

$4580 \pm 90$ $2630 \mathrm{BC}$

Samples coll and subm 1974 by $\mathrm{H} \mathrm{W}$ Scharpenseel and H Grottenthaler. Comment: tuffaceous material believed identical to age of better studied tuff below Erdinger moos, dated to Atlantic time. fA6 horizon is lignitic. Maximum date is slightly younger than expected: 7000 to 5000 yr BP.

HAM-44. Pit of brick factory Fellheim, between $4340 \pm 130$ Fellheim and Boos. Loess loam overlying gravel $2390 \mathrm{BC}$ of nether terrace of Iller R, fBt near boundary between terrace gravel and loess loam $\left(48^{\circ} 4^{\prime} \mathrm{N}\right.$, $\left.10^{\circ} 10^{\prime} \mathrm{E}\right), 0.5 \% \mathrm{C}$, IIBvt 115 to $130 \mathrm{~cm}$.

HAM-45. Transition to nether (lowest terrace level) terrace gravel, $0.3 \% \mathrm{C}$, IIBC 130 to $150 \mathrm{~cm}$. 
HAM-46. Pit Heimertingen, geol as above. Fossil Bt at

$1150 \pm 80$ boundary to terrace gravel, but closer to soil

AD 800 surface $\left(48^{\circ} 3^{\prime} \mathrm{N}, 10^{\circ} 9^{\prime} \mathrm{E}\right), 0.4 \% \mathrm{C}$,

IIBvt 85 to $110 \mathrm{~cm}$.

Samples coll and subm 1974 by $\mathrm{H}$ W Scharpenseel and H Grottenthaler. Comment: it is not known whether carbon of fossil horizon was formed in situ or if most of it was transported, perhaps through secondary pores, especially rain worm tubes. Dates, especially HAM-46 (Heimertingen), do not agree with origin of soil in Würm interstadial or early Holocene. Young carbon immigration from top soil seems considerable.

Soil profiles in Nördlinger Ries crater.

HAM-47. Eutrochrept, deep humic brown earth, near $\quad 5920 \pm 100$ Hohentrüdingen in loam on Jurassic (Dogger) $3970 \mathrm{BC}$ bedrock, $\left(49^{\circ} 0^{\prime} \mathrm{N}, 10^{\circ} 42^{\prime} \mathrm{E}\right), 3.0 \% \mathrm{C}$, AhBvl 25 to $40 \mathrm{~cm}$.

HAM-48. $2.7 \%$ C, AhBv2 40 to $60 \mathrm{~cm}$ $10,360 \pm 140$ 8410 BC

HAM-49. $1.6 \% \mathrm{C}, \mathrm{Cv} 60$ to $80 \mathrm{~cm}$ $15,730 \pm 410$ $13,780 \mathrm{BC}$

HAM-50. Vertisol on tertiary Ries deposits, $3750 \pm 80$ $300 \mathrm{~m}$ E Maihingen $\left(48^{\circ} 65^{\prime} \mathrm{N}, 10^{\circ} 31^{\prime} \mathrm{E}\right)$, $3.8 \% \mathrm{C}$, BvAh 40 to $60 \mathrm{~cm}$.

HAM-51. $1.5 \% \mathrm{C}, \mathrm{AhBv} 60$ to $80 \mathrm{~cm}$

HAM-52. $0.6 \% \mathrm{C}$, BvCvI 80 to $100 \mathrm{~cm}$

HAM-53. $\quad 0.9 \% \mathrm{C}, \mathrm{BvCv} 2100$ to $120 \mathrm{~cm}$

HAM-54. $0.6 \%$ C, BvCv3 120 to $140 \mathrm{~cm}$ $1800 \mathrm{BC}$ $5660 \pm 90$ $3710 \mathrm{BC}$

$7060 \pm 110$ $5110 \mathrm{BC}$

$5680 \pm 90$ 3730 вС

$8710 \pm 120$ $6760 \mathrm{BC}$

HAM- $55 . \quad 0.5 \%$ C, IIfAh 140 to $160 \mathrm{~cm}$

HAM-56. Vertisol-Gley on younger Ries lake deposits, Pfäfflingen $\left(48^{\circ} 56^{\prime} \mathrm{N}, 10^{\circ} 34^{\prime} \mathrm{E}\right), 2.6 \% \mathrm{C}$, GoAh2 30 to $50 \mathrm{~cm}$.

$11,820 \pm 170$ 9870 вC

$3640 \pm 70$ 1690 BC

HAM-57. $1.7 \%$ C, AhGol 50 to $80 \mathrm{~cm}$ $4880 \pm 80$ 2930 вС

HAM-58. $1.0 \%$ C, AhGo2 80 to $110 \mathrm{~cm}$ $4840 \pm 90$ $2890 \mathrm{BC}$ 
HAM-59. $0.5 \%$ C, AhGro 110 to $130 \mathrm{~cm}$

$7590 \pm 100$

5640 вС

HAM- $60.4 .0 \%$ C, Gor 130 to $140 \mathrm{~cm}$

$10,470 \pm 160$

8520 BC

HAM-61. Vertisol-Pseudogley, Ries lake deposits,

$3300 \pm 80$ Wechingen $\left(48^{\circ} 56^{\prime} \mathrm{N}, 10^{\circ} 36^{\prime} \mathrm{E}\right), \mathrm{AhSw}$

$1350 \mathrm{BC}$ 30 to $50 \mathrm{~cm}$.

HAM-62. SwSd 50 to $70 \mathrm{~cm}$

$3860 \pm 80$

$1910 \mathrm{BC}$

HAM-63. Vertisol-Braunerde, Ries lake deposits, Munningen $3980 \pm 70$ $\left(48^{\circ} 63^{\prime} \mathrm{N}, 10^{\circ} 35^{\prime} \mathrm{E}\right), \mathrm{Bv} 25$ to $50 \mathrm{~cm}$.

2030 BC

$4840 \pm 60$

HAM-64. BvCv 50 to $70 \mathrm{~cm}$

$2890 \mathrm{BC}$

Samples coll and subm 1974 by H W Scharpenseel and G Rückert, Bayrisches Geol Landesamt, Munich. Comment: geol and pedol survey (Schmidt-Kaler \& Treibs, 1970; Rückert, 1975) of the Ries indicate occurrence of vertisolic soils, otherwise rare in W German climate. Vertisols are best qualified for ${ }^{14} \mathrm{C}$-dating, especially below cracking zone (Scharpenseel, 1972) Ries samples indicate soil formation at least since Alleröd time. HAM-49 was a very small sample from a highly calcareous substrate. Age 15,730 yr needs reconfirmation. The rather shallow Wechingen, HAM-61, 62 and Munningen profiles, HAM-63, 64, apparently have not yet outgrown rejuvenated range due to root growth and animal transport. Maximum dates, ca 11,000 yr are as expected.

HAM-65. Near Landshut nethermoor, Koislhof, $\quad 10,960 \pm 180$ Profile 2, $4.6 \%$ C, 130 to $150 \mathrm{~cm}$

$9010 \mathrm{BC}$

Sample coll and subm 1974 by B Hofmann, Bayrisches Geol Landesamt, Munich. Comment: samples serve to reconfirm findings of HAM-14 to -21 from another sampling spot of same geol situation. Reconfirmation of Alleröd age of nethermoor is perfect.

Smonica/Chernozem-like soils in Rheinhessen.

HAM-66. Smonica, Vertisol-like soil, SW Lötzweiler, $\quad 2740 \pm 70$ M2 Ah 60 to $80 \mathrm{~cm}$ (R 345069, H 552938)

$790 \mathrm{BC}$

HAM-67. Smonica Lö I, fAh 95 to $115 \mathrm{~cm}$

$5430 \pm 90$ $3480 \mathrm{BC}$

HAM-68. Chernozem Lö II, M 30 to $40 \mathrm{~cm}$ $2580 \pm 70$ 530 вС

HAM-69. Chernozem, fAh 55 to $70 \mathrm{~cm}$ $2010 \pm 60$ $60 \mathrm{BC}$

Samples coll and subm 1974 by H Zakosek, Amt f Bodenforschung Wiesbaden. Comment: sampling spots all close together. Ham-67 indicates 
supposed age of soil formation during Boreal/Atlantic periods. Others apparently rejuvenated by intact recent biodynamics. Aim of study, genetic and systematic position of Smonica in central Europe.

Steppe soils below colluvium in loess as parent material, region of Fritzlar, Hessen.

HAM-70. Transition Mollisol-Hapludalf, Dorla I/2, $\quad 3300 \pm 70$ Km 21 Fritzlar-Gudensberg Hwy 1350 вс $\left(51^{\circ} 11^{\prime} \mathrm{N}, 9^{\circ} 20^{\prime} \mathrm{E}\right)$, fAh 90 to $110 \mathrm{~cm}$

HAM-71. Transition Mollisol-Hapludalf, Lohne I, $\mathrm{N}$ village of Lohne $\left(51^{\circ} 11^{\prime} \mathrm{N}, 9^{\circ} 16^{\prime} \mathrm{E}\right)$, $2040 \pm 60$ $90 \mathrm{BC}$ Ah 40 to $50 \mathrm{~cm}$

HAM-72. Transition Mollisol-Hapludalf, Wehren $2890 \pm 70$ I/2, Wehren-Kirchberg St, $\left(51^{\circ} 11^{\prime} \mathrm{N}\right.$, $\left.9^{\circ} 18^{\prime} \mathrm{E}\right)$, Ah 35 to $55 \mathrm{~cm}$

940 вС

HAM-73. Transition Mollisol-Hapludalf, Wehren $\quad 4740 \pm 80$ I/3, Wehren-Kirchberg St, $\left(51^{\circ} 11^{\prime} \mathrm{N}, \quad 2790\right.$ BC $9^{\circ} 18^{\prime} \mathrm{E}$ ), AlBt 60 to $80 \mathrm{~cm}$

Samples coll and subm 1974 by C Haupenthal, Amt f Bodenforschung, Wiesbaden. Comment: aim is systematic study of steppe soils in slight depressions; classification to Mollisols or Hapludalfs. HAM-71, 72, at 40 to $55 \mathrm{~cm}$ depth, are rejuvenated by root growth and animal transport, HAM- 70 , at 90 to $110 \mathrm{~cm}$, is younger than expected, only HAM-73 comes close to ${ }^{14} \mathrm{C}$ age commonly found at fringes of A-horizon of Mollisols (Scharpenseel, 1972).

HAM-74. Mollisol Heuchelheim, colluvial loess-loam $\quad 3660 \pm 90$ on top of degraded Chernozem, $\left(50^{\circ} 23^{\prime} \mathrm{N}, \quad 1710 \mathrm{BC}\right.$ $\left.8^{\circ} 52^{\prime} \mathrm{E}\right) 1.0 \% \mathrm{C}$, fAh 70 to $85 \mathrm{~cm}$

HAM-75. Gleichen II, "Im Grund", middle slope, $6480 \pm 80$ colluvium of loess loam on top of degraded 4530 вС Chernozem $\left(51^{\circ} 13^{\prime} \mathrm{N}, 9^{\circ} 20^{\prime} \mathrm{E}\right)$, $1.0 \%$ C, fAh 240 to $260 \mathrm{~cm}$.

Samples coll and subm 1974 by C Haupenthal and S Schrader, Amt f Bodenforschung, Wiesbaden. Comment: HAM-75, an fAh outside root growth and animal transport, indicates expected age of Boreal/Atlantic origin. Aim is classification of colluvium capped steppe soils.

Soil samples from loess loam and underlying solifluction debris, Vogelsberg, Hessen.

HAM-76. $1.2 \mathrm{~km} \mathrm{~S} \mathrm{Höingen,} \mathrm{Vogelsberg,} \mathrm{loess} \mathrm{loam}$ overlying solifluction debris, below tuffaceous $10,550 \pm 130$ pumice of lake of Laach Alleröd volcanism $8600 \mathrm{BC}$ $\left(50^{\circ} 42^{\prime} \mathrm{N}, 9^{\circ} 55^{\prime} \mathrm{E}\right)$, fA $120 \mathrm{~cm}$ 
HAM-77. 300m E Taufstein (High Vogelsberg), upper $2540 \pm 70$ part of solifluction debris (mixture of loess loam $590 \mathrm{BC}$ as well as tuffaceous pumice and basalt) $\left(50^{\circ} 31^{\prime} \mathrm{N}, 9^{\circ} 14^{\prime} \mathrm{E}\right), 20$ to $40 \mathrm{~cm}$

HAM-78. Same spot, lower part $(>40 \mathrm{~cm})$ of solifluction debris.

Samples coll and subm 1973 by E Schönhals, Inst $\mathrm{f}$ Bodenkunde, Univ Giessen. Comment: HAM-76 had to reveal, whether the fA-horizon was in situ below Alleröd-time trachyt ashes or transported by percolation through porous tuff material. Date confirms formation in situ. HAM77-78 should determine whether the solifluction debris was uniform also in age, or deposited stepwise. Large difference in age supports the latter.

High flood loam, plane S of Main R.

HAM-79. High flood loam of Main, KelsterbachLerchenberg, Kiesgrube Schmidt, loam $7700 \pm 170$ contains charcoal particles, (R 346789 , 5750 вС H 5549 71, sheet Kelsterbach), IIfAhBtx

HAM-80. Same spot and horizon (IIfAhBtx), without charcoal, humus-C only

HAM-81. Fossil A-horizon adjacent to Alleröd-time trachyt tuff of Laach-volcanism, in sandy deposits of Plane S Main R, Buchschlag 8050 BC III, material enriched with charcoal.

Samples coll and subm 1973 by W Plass, Inst Geog, Univ Frankfort. Comment: HAM-79-80 indicate, that in same material charcoal-C is not older than humus-C. HAM-81 falls slightly short of expected value, $>$ $10,500 \mathrm{yr}$. Slash in age probably due to percolation of younger humus-C in rather sandy and acid substrate accompanied by some deep racination.

Colluvial loam, valley fillings, Hochheim and Waldeck.

HAM-82. Colluvial loam, Hochheim, Water Sta Hattersheim, $140 \mathrm{~cm}$ below surface $\left(50^{\circ} 3^{\prime} \mathrm{N}, 8^{\circ} 28^{\prime} \mathrm{E}\right)$

$$
\begin{array}{r}
1020 \pm 60 \\
\operatorname{AD} 930
\end{array}
$$

HAM-83. Colluvial loam, Hochheim, Hattersheim, dark horizon $50 \mathrm{~cm}$ below surface $\left(50^{\circ} 3^{\prime} \mathrm{N}, 8^{\circ} 28^{\prime} \mathrm{E}\right)$

HAM-84. Colluvial loam, Hochheim, slightly sandy loess loam with some humus over crude loess, 130 to $150 \mathrm{~cm}$ below surface $\left(50^{\circ} 4^{\prime} \mathrm{N}, 8^{\circ} 28^{\prime} \mathrm{E}\right)$

HAM-85. Colluvial loam, Hochheim, foot of slope accumulation, calcareous sandy loam, $\left(50^{\circ} 2^{\prime} \mathrm{N}, 8^{\circ} 25^{\prime} \mathrm{E}\right), 140$ to $150 \mathrm{~cm}$

$$
\begin{array}{r}
1570 \pm 70 \\
\operatorname{AD} 380
\end{array}
$$

$$
1760 \pm 70
$$

AD 190

$$
3180 \pm 70
$$

$1230 \mathrm{BC}$ 
HAM-86. Colluvial loam, Hochheim, foot of slope $2450 \pm 70$ accumulation, $\left(50^{\circ} 2^{\prime} \mathrm{N}, 8^{\circ} 25^{\prime} \mathrm{E}\right), 100$ to $120 \mathrm{~cm} \quad 500 \mathrm{BC}$

HAM-87. Colluvial loam, Hochheim, humus-rich $6230 \pm 100$ horizon in foot of slope accumulation, $\quad 4280 \mathrm{BC}$ 90 to $110 \mathrm{~cm},\left(50^{\circ} 2^{\prime} \mathrm{N}, 8^{\circ} 25^{\prime} \mathrm{E}\right)$

HAM-88. Colluvial loam, Hochheim, slopy terrace, $28^{\circ}$ inclination, 80 to $100 \mathrm{~cm}\left(50^{\circ} 2^{\prime} \mathrm{N}, 8^{\circ} 26^{\prime} \mathrm{E}\right)$

HAM-89. Colluvial loam, Hochheim, terrace plane, $<2^{\circ}$ inclination, 120 to $140 \mathrm{~cm},\left(50^{\circ} 2^{\prime} \mathrm{N}, 8^{\circ} 26^{\prime} \mathrm{E}\right)$

HAM-90. Colluvial loam, Hochheim, slightly humic cover on terrace pebbles, sandy-loamy, 80 to $100 \mathrm{~cm}\left(50^{\circ} 4^{\prime} \mathrm{N}, 8^{\circ} 23^{\prime} \mathrm{E}\right)$

HAM-91. Colluvial loam, Hochheim, Delkenheim, fA 40 to $60 \mathrm{~cm}$ below surface $\left(50^{\circ} 3^{\prime} \mathrm{N}, 8^{\circ} 22^{\prime} \mathrm{E}\right)$

$2050 \pm 70$ $100 \mathrm{BC}$

$2580 \pm 100$ $630 \mathrm{BC}$

$580 \pm 120$ AD 1370

$$
1970 \pm 70
$$

$20 \mathrm{BC}$

HAM-92. Colluvial loam, Hochheim, Delkenheim, slopy site, between foss A-horizons,

$2330 \pm 80$ 380 вС 100 to $120 \mathrm{~cm}\left(50^{\circ} 3^{\prime} \mathrm{N}, 8^{\circ} 22^{\prime} \mathrm{E}\right)$

HAM-93. Colluvial loam, Hochheim, Delkenheim, humic basis horizon over loess loam, 80 to $100 \mathrm{~cm}\left(50^{\circ} 3^{\prime} \mathrm{N}, 8^{\circ} 22^{\prime} \mathrm{E}\right)$

HAM-94. Colluvium, Waldeck, Freienhagen, dark humic loamy sand over sandstone debris, 70 to $90 \mathrm{~cm}\left(50^{\circ} 16^{\prime} \mathrm{N}, 9^{\circ} 4^{\prime} \mathrm{E}\right)$

HAM-95. Colluvium, Waldeck, Ippinghausen, slopy part over sandstone debris, loamy sand with little humus, AD 1130 50 to $80 \mathrm{~cm}\left(50^{\circ} 17^{\prime} \mathrm{N}, 9^{\circ} 9^{\prime} \mathrm{E}\right)$

Samples coll and subm 1973 by J Gie $\beta$ übel, Inst Geog, Univ Frankfort. Comment: colluvial Valley fillings rather young, but mostly older than those of medieval deforestation. Humic basis horizons with 6000 to 7000 yr apparently Boreal/Atlantic in origin (Thesis, Frankfort, in press).

Podzol-"Raseneisengley" soils of Black Forest, Rotes Meer near Altglashütten.

HAM-96. Samples from freshly opened profiles "Rotes Meer, between Altglashütten and Bärental $\left(47^{\circ} 51.5^{\prime} \mathrm{N}, 8^{\circ} 6^{\prime} \mathrm{E}\right), 20.3 \% \mathrm{C}, \mathrm{Oh}$

HAM-97. Same sample, charcoal only $200 \pm 60$

HAM-98. Same profile, Go II, brown AD 1120 $830 \pm 180$ $1850 \pm 60$ AD 100 
HAM-99. Same profile, Go II, black-brown

HAM-100. Same profile, sandy peaty horizon

HAM-101. Same profile, Bh AD 1370

$$
580 \pm 60
$$

HAM-102. Same profile, Bs

Samples coll and subm 1974 by K Stahr, Inst Soil Sci, Freiburg Univ. Comment: Podzol formation expected in Alleröd time, older Dryas, or time after deforestation-17th century. Due to permanent organic matter percolation, date of Podzol is at best minimum age. Origin after deforestation, 17th century, can be excluded. Rather recent date of charcoal in $\mathrm{Oh}$ horizon is insignificant for origin of soil formation.

Placorthods, "Bändchen-Podsole" from Wales

HAM-103. Hiraethog, Denbighmors, Denbigshire Mynydd Aled near Landmans Arms $\left(53^{\circ} 10^{\prime} \mathrm{N}, 3^{\circ} 30^{\prime} \mathrm{W}\right) 45.0 \% \mathrm{C}, \mathrm{Oh}$

$$
580 \pm 60
$$

AD 1370

$$
\begin{aligned}
& 1420 \pm 60 \\
& 530 \mathrm{BC} \\
& 5810 \pm 150 \\
& 3860 \mathrm{BC}
\end{aligned}
$$

HAM-108. Same profile, twig at basis of Oh

HAM-105. Peny Gwrydd-pass, Snowdonia Natl Park, Caernarvonshire $\left(53^{\circ} 5^{\prime} \mathrm{N}, 4^{\circ} 2^{\prime} \mathrm{W}\right)$, "Bändchen-Stagnogley" Oh, $13.7 \%$ C

$$
\begin{aligned}
& 4010 \pm 70 \\
& 2060 \text { BC } \\
& 1290 \pm 60 \\
& \text { AD } 660
\end{aligned}
$$

$1770 \pm 80$ AD 180

HAM-106. Same profile, $5.6 \%$ Ahf

Samples coll and subm 1974 by K Stahr. Comment: HAM-103-104 date Placorthod Formation, also HAM-105-106 date time for ligand formation, minimum is ca $1300 \mathrm{yr}$. Twig (HAM-108) was found at basis of Oh horizon, coal-like substance in Bs BvC horizon, where it dates erosion and settlement phase.

Comparison of humus-C and charcoal dates of Black Forest Podzol.

HAM-109. Soil sample, S Black Forest, between Breitnau and Hollertal, Breitnau I, Podzol Oh/Ah

$$
\begin{array}{r}
1120 \pm 60 \\
\text { AD } 830 \\
560 \pm 70 \\
\text { AD } 1390
\end{array}
$$

HAM-110. Same profile and sample, only charcoal 
HAM-111. Soil sample S Black Forest, between Breitnau and Hollertal, Breitnau II, Podzol Oh/Ah

HAM-112. Same profile and sample, only charcoal

$\begin{aligned} & 490 \pm 70 \\ & \text { AD } 1460\end{aligned}$ $530 \pm 80$ AD 1420

HAM-113. Charcoal pile, Trescher, 0 to $10 \mathrm{~cm}$, $\mathrm{Oh} / \mathrm{Ah},\left(47^{\circ} 57^{\prime} \mathrm{N}, 8^{\circ} 7^{\prime} \mathrm{E}\right)$

$103.4 \pm 0.5 \%$

$$
420 \pm 50
$$

HAM-114. Same spot, charcoal, upper portion, 10 to $30 \mathrm{~cm}$ AD 1530

HAM-115. Same spot, charcoal, lower portion, 30 to $50 \mathrm{~cm}$

$$
340 \pm 60
$$

AD 1610

$1040 \pm 50$

AD 910

HAM-116. Fossil Brown earth, fAh 50 to $70 \mathrm{~cm}$

$102.5 \pm 0.4 \%$

HAM-117. Brown earth Trescher, below rough humus cover, Ah

Samples coll and subm 1974 by K Stahr. Comment: since podzols have extremely strong rejuvenation due to percolation of rough humus-C, by charcoal in podzol, we hoped to find gap between charcoal and humus dates caused by rejuvenation. Breitnau I showed reverse trend, humus-C being older than charcoal-C, which apparently entered soil later. Breitnau II gives equal results for humus-C and charcoal-C. Charcoal pile Trescher was army camp at beginning of 18th century. Charcoal reflects tree age plus time after conversion into charcoal. Humus- $\mathrm{C}$ age in Ah-horizons affected by bomb-C, fAh of Brown earth in subsoil relatively oldest, old land surface before charcoal pile construction and army lodging. Parallel dating of charcoal and humus-C of same horizon for estimate of rejuvenating effect on humus-C is disappointing with humus-podzols due to their young age.

Low moor peat, charcoal and fossil soil on Riss boulder marl, Altenerding, Bavaria.

HAM-118. Charcoal, old fireplace, in loess Brown earth 40 to $50 \mathrm{~cm}$ (H $534505, \mathrm{R} 449295$ )

$$
1920 \pm 160
$$
AD 30

HAM-119. Low moor peat in between loess and Riss boulder marl, 4 to $5 \mathrm{~m}$ (H 534525 , R 4496 35)

$30,340 \pm 1130$ $28,390 \mathrm{BC}$

$28,840 \pm 940$

HAM-120. Another spot of the same pit 26,890 вС

HAM-121a. Low moor peat below 4 to $5 \mathrm{~m}$ tuffaceous limestone; sample contains carbonates,

$8470 \pm 110$ $6520 \mathrm{BC}$ 
HAM-121b. Same sample in spot without carbonates

$8490 \pm 100$

HAM-122. Buried Ah horizon of soil, formed in Riss

$6540 \mathrm{BC}$

boulder marl below colluvium of slope (H 5345 05, R 4492 95)

$5550 \pm 100$

3600 вС

Samples coll and subm 1973 by U Schwertmann, Inst Soil Sci, Tech Univ Munich. Comment: aim was to date low moor peat between loess and Riss boulder marl; further below 4 to $5 \mathrm{~m}$ tuffaceous limestone, a recent Brown Earth in loess, and buried soil below colluvium, in the Altenerding area. Peat seems to originate from Paudorf interstadial and may be Alleröd with some rejuvenation or Boreal/Atlantic time with some older materials included. Buried soil below colluvium seems to date from climatic optimum Boreal/Atlantic time with some rejuvenation due to root growth and animal transport.

Samples describing Eastern Sea coastline changes, SW Heiligenhafen

HAM-123. Cliff wall, till $150 \mathrm{~cm}$ below surface, $70 \mathrm{~cm}$ below fossil beech sediment

$4020 \pm 90$ $\left(54^{\circ} 29^{\prime} \mathrm{N}, 10^{\circ} 55^{\prime} \mathrm{E}\right)$

HAM-124. Cliff wall, $2 \mathrm{~m}$ depth, low moor below same

fossil beech sediment $\left(54^{\circ} 22^{\prime} \mathrm{N}, 10^{\circ} 55^{\prime} \mathrm{E}\right)$

2070 вС

$$
\begin{gathered}
2070 \pm 70 \\
120 \mathrm{BC}
\end{gathered}
$$

HAM-125. Cliff wall, 45 to $90 \mathrm{~cm}$, underlying fossil beech sediment $\left(54^{\circ} 22^{\prime} \mathrm{N}, 10^{\circ} 55^{\prime} \mathrm{E}\right)$

$$
\begin{array}{r}
1140 \pm 60 \\
\operatorname{AD} 810
\end{array}
$$

HAM-126. Cliff wall 90 to $110 \mathrm{~cm}$ below beech sediment $\left(54^{\circ} 22^{\prime} \mathrm{N}, 10^{\circ} 55^{\prime} \mathrm{E}\right)$

$$
1990 \pm 60
$$

$40 \mathrm{BC}$

HAM-127. Cliff wall 110 to $125 \mathrm{~cm}$ below fossil beech sediment $\left(54^{\circ} 22^{\prime} \mathrm{N}, 10^{\circ} 55^{\prime} \mathrm{E}\right)$.

Samples coll and subm 1974 by D Goetz, Ordinariat f Bodenkunde, Hamburg Univ. Comment: studied to elucidate earliest time of beech wall formation, and to estimate highest water level of Eastern Sea. Estimations of ca $2000 \mathrm{yr}$ were met, except for HAM-125, in rather high position, and HAM-123, $70 \mathrm{~cm}$ below beech sediment, where $4000 \mathrm{yr}$ suggest older origin of this beech wall, closer to climatic optimum of region.

Fossil Chernozem samples

HAM-128. Outskirts of Homberg, Kassel Co, 110 to $130 \mathrm{~cm} \mathrm{fA}\left(51^{\circ} 2^{\prime} \mathrm{N}, 9^{\circ} 6^{\prime} \mathrm{E}\right)$

$$
\begin{aligned}
& 5650 \pm 80 \\
& 3700 \mathrm{BC} \\
& 3530 \pm 70 \\
& 1580 \mathrm{BC}
\end{aligned}
$$

HAM-129. Worms I, near town of Worms, fAh, 80 to $90 \mathrm{~cm}$

Samples coll and subm 1974 by G Haupenthal, Hessisches Landesamt f Bodenforschung, Wiesbaden. Comment: HAM-128, from Homberg, dated at 5000 BC by Fritzlar Mus based on band ceramic relics; fA-material of Worms apparently slightly rejuvenated by roots and animal transport, since soils are believed to date from Atlantic period. 
Bones and wood in sediment layer believed from Roman time

HAM-130. Bones in lower pebble layer, near Xanten (collagen date), $\left(51^{\circ} 39^{\prime} \mathrm{N}, 6^{\circ} 32^{\prime} \mathrm{E}\right)$

$$
1680 \pm 50
$$
AD 270

HAM-131. Same spot, wood buried in middle sand

$$
\begin{gathered}
1980 \pm 70 \\
30 \mathrm{BC} \\
2180 \pm 60 \\
230 \mathrm{BC} \\
3150 \pm 70 \\
1200 \mathrm{BC}
\end{gathered}
$$

HAM-132. Same spot, dark gray silty loam between middle sand and pebbles

Samples coll and subm 1974 by E Mückenhausen, Inst f Bodenkunde, Bonn Univ. Comment: good confirmation of Roman origin, except for deepest bluish silty fine sand.

Deeply humic soils near Dutch border; organic matter in deeper part of profiles due to plaggen culture or deep plowing

HAM-134. Walbeker Heide, gravel pit, humic eolian sand, believed from Alleröd time, 120 to $140 \mathrm{~cm}\left(51^{\circ} 30^{\prime} \mathrm{N}, 6^{\circ} 15^{\circ} \mathrm{E}\right)$

$$
\begin{gathered}
8340 \pm 90 \\
6390 \mathrm{BC} \\
9580 \pm 100 \\
7630 \mathrm{BC} \\
1540 \pm 60 \\
\text { AD } 410 \\
2070 \pm 90 \\
120 \mathrm{BC} \\
1440 \pm 50 \\
\text { AD } 510 \\
1860 \pm 90 \\
\text { AD } 90 \\
1250 \pm 50 \\
\text { AD } 700 \\
1440 \pm 60 \\
\text { AD } 510 \\
1175 \pm 50 \\
\text { AD } 775
\end{gathered}
$$

HAM-135. Same sample, 6 N HCl-hydrolysis residue only bruck, 50 to $70 \mathrm{~cm}\left(51^{\circ} 32^{\prime} \mathrm{N}, 6^{\circ} 25^{\prime} \mathrm{E}\right)$

HAM-139. Same sample, 6 N HCl-hydrolysis residue only

HAM-140. Humic sand loess, Schandelah, 45 to $60 \mathrm{~cm}$

$1880 \pm 130$ AD 70

HAM-143. Same sample, 6 N HCl-hydrolysis residue only

Samples coll and subm 1974 by D Schröder, Inst f Bodenkunde, Bonn Univ. Comment: deeply humic material could be derived from past landsurface horizons, as well as from plaggen covers or from deeply humic 
horizon due to deep plowing. Total sample and $6 \mathrm{~N} \mathrm{HCl}$ hydrolysis residue were parallel-dated, because hydrolysis residue samples were expected to be older. Ages older than 1500 to 2000 yr could safely be excluded from plaggen origin, since it is essentially a medieval technique of soil improvement. Since fossil carbon can be present in plaggen material, eg, from coal ashes, all samples, except for Walbeker Heide with soil formation close to Alleröd, could be due to plaggen culture (Mückenhausen et al, 1968).

\section{B. Austria}

HAM-144. Low moor, Neumarkt, Am Wallersee, state of Salzburg, underneath low moor calcareous $2790 \pm 90$ silt, 90 to $100 \mathrm{~cm}\left(47^{\circ} 40^{\prime} \mathrm{N}, 13^{\circ} 10^{\prime} \mathrm{E}\right)$

HAM-145. Same profile, 160 to $170 \mathrm{~cm}$

$3770 \pm 70$ $1820 \mathrm{BC}$

Samples coll and subm by F Blümel, Federal Inst Cultural Technique, Petzenkirchen. Comment: aim of study was to date beginning of low moor formation. Dates are somewhat younger than estimated $5000 \mathrm{yr}$.

\section{USSR}

HAM-146. Southern Predkaokadzye Chernozem, ca $130 \mathrm{~km} \mathrm{~S}$ Rostov, $1.5 \% \mathrm{C}, 180$ to $200 \mathrm{~cm}$, Profile 1

HAM-147. Chernozem of nether terrace of Don R, crotovines in C-horizon, $1.2 \% \mathrm{C}, 95 \mathrm{~cm}$, Profile 2

HAM-148. Meadow Chernozem in Asow system $0.2 \%$ C, Profile 3

HAM-149. Dark Gray Forest soil on diluvium of carboniferous limestone (Zhiguli State Reserve), $0.4 \%$ C, BC, 70 to $80 \mathrm{~cm}$, Profile 6

HAM-150. Paleohydromorphic Chernozem, Crotovine, $4.1 \% \mathrm{C}, 85 \mathrm{~cm}$, Profile 9

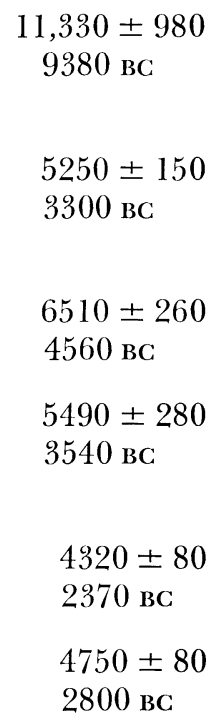

$5250 \pm 150$ $3300 \mathrm{BC}$

$6510 \pm 260$ 4560 вС

$5490 \pm 280$ 3540 BC

$4320 \pm 80$ $2370 \mathrm{BC}$ $4750 \pm 80$ $2800 \mathrm{BC}$

HAM-151. Same Profile, $8.3 \%$ C, $110 \mathrm{~cm}$

HAM-152. Typical Chernozem from Privolzhye Upland, Karlinsky State Farm, Ulyanovsk Dist, $5390 \pm 120$ 3440 вс

HAM-153. Normal Chernozem, near Meadow Solod, $5550 \pm 140$ outskirts Ulyanovsk Agric Inst campus, 3600 вС $1.0 \% \mathrm{C}, \mathrm{BC}, 110 \mathrm{~cm}$, Profile 16 
HAM-154. Gray Forest soil, Serp-i-molot collective $7890 \pm 680$ farm, Vysokogorsky region, Tatar ASSR 5940 вс $0.3 \%$ C, B $3 \mathrm{t}$, ca $140 \mathrm{~cm}$, Profile 19

Samples coll and subm 1974 by H W Scharpenseel. Samples coll during Wolga-Don excursion, 10th Internatl Cong Soil Sci, Moscow, 1974. Profile numbers refer to excursion guide (Ivanov, 1974). Comment: most samples indicate ages from 5000 to 6300 yr as usual in European chernozems, suggesting main phase of formation during Atlantic period. HAM146 and -154 were small samples.

HAM-155. Chernozem from Tour I, 10th Internatl $\quad 4540 \pm 80$ Cong Soil Sci, $0.6 \%$ C, AC, 80 to $90 \mathrm{~cm}$, Profile 3. $2590 \mathrm{BC}$

HAM-156. Same profile, 18 to $40 \mathrm{~cm}$ $2350 \pm 50$ $400 \mathrm{BC}$

Samples coll and subm by $\mathrm{C}$ Haupenthal, Hessisches Landesamt f Bodenforschung, Wiesbaden. Comment: dates agree with expected ages at sampling levels. Some rejuvenation due to root growth and animal transport is likely even in HAM-155.

\section{Tunisia}

Fossil horizons in steppe and alluvial soils of the semiarid region

HAM-157. Fossil soil in pasture experimental plot, Ain Oktor, Korbous, $0.3 \%$ C, fA, 80 to $100 \mathrm{~cm}\left(36^{\circ} 48^{\prime} \mathrm{N}, 10^{\circ} 34^{\prime} \mathrm{E}\right)$

HAM-158. Three fossil horizons, Ferme near Korba, pasture experiment, $0.2 \% \mathrm{C}, \mathrm{fAl}$, 48 to $60 \mathrm{~cm}\left(36^{\circ} 35^{\prime} \mathrm{N}, 10^{\circ} 53^{\prime} \mathrm{E}\right)$ AD 1230

$$
\begin{aligned}
& 2250 \pm 60 \\
& 300 \mathrm{BC}
\end{aligned}
$$

HAM-159. Same profile, $0.1 \% \mathrm{C}, \mathrm{fA} 2,115$ to $125 \mathrm{~cm}$

$1300 \pm 60$
$\mathrm{AD} 650$

HAM-160. Same profile, $0.1 \% \mathrm{C}, \mathrm{fA} 3,160$ to $175 \mathrm{~cm}$

$$
\begin{aligned}
& 2300 \pm 100 \\
& 350 \mathrm{BC}
\end{aligned}
$$

HAM-161. Two fossil horizons near Ferme Korba, profile in plot of pasture experiments, $0.3 \% \mathrm{C}$,

$1030 \pm 60$ fA 1,60 to $80 \mathrm{~cm}\left(36^{\circ} 35^{\prime} \mathrm{N}, 10^{\circ} 53^{\prime} \mathrm{E}\right)$

HAM-162. Same profile, $0.4 \%$ C, fA2, 110 to $130 \mathrm{~cm}$

$2470 \pm 70$

520 вC

HAM-163. Fossil horizon, Ferme Ennasser near Bir Bou Rekba, 0.6\% C, fAl, 180 to $4230 \pm 60$ $190 \mathrm{~cm}\left(36^{\circ} 26^{\prime} \mathrm{N}, 10^{\circ} 33^{\prime} \mathrm{E}\right)$

2280 BC

HAM-164. Same region profile nearby higher slope, $0.8 \% \mathrm{C}, \mathrm{fAl}, 105$ to $115 \mathrm{~cm}$ 
HAM-165. Fossil horizon near Enfida, Km 52, rd $4510 \pm 80$ to Kairouan, $0.9 \%$ C, fA1, 75 to $90 \mathrm{~cm}$ 2560 BC $\left(36^{\circ} 6^{\prime} \mathrm{N}, 10^{\circ} 21^{\prime} \mathrm{E}\right)$

HAM-166. Fossil horizons in Medjerdah alluvium, near Ghardimaou bridge, $\mathrm{fAl}, 70$ to $90 \mathrm{~cm}$ $\left(36^{\circ} 26^{\prime} \mathrm{N}, 8^{\circ} 27^{\prime} \mathrm{E}\right)$

$6450 \pm 100$

$4500 \mathrm{BC}$

$8000 \pm 180$

HAM-167. Same location of alluvium, fA2, 250 to $270 \mathrm{~cm}$ $6050 \mathrm{BC}$

HAM-168. Fossil horizons in Medjerdah alluvium, near Bou Salem, $2.4 \% \mathrm{C}, \mathrm{fAl}, 35$ to $40 \mathrm{~cm}$ $\left(36^{\circ} 37^{\prime} \mathrm{N}, 8^{\circ} 57^{\prime} \mathrm{E}\right)$

HAM-169. Same location of alluvium, $1.5 \% \mathrm{C}$, fA2, 90 to $110 \mathrm{~cm}$

$670 \pm 60$ AD 1280

$5050 \pm 80$ $3100 \mathrm{BC}$

$4500 \pm 80$

HAM-170. Location nearby, $1.5 \%$ C, fA2, 85 to $95 \mathrm{~cm}$ 2550 вС

HAM-171. Same location, $1.2 \%$ C, fA3, 120 to $140 \mathrm{~cm}$ $7800 \pm 160$ 5850 BC

HAM-172. Location nearby, near Bou Huertma R, $0.4 \% \mathrm{C}, 300 \mathrm{~cm}$

$2170 \pm 170$ 220 BC

HAM-173. Drainage ditch nearby, $0.8 \% \mathrm{C}, 100 \mathrm{~cm}$ $1220 \pm 60$ AD 730

HAM-174. Same location $0.7 \%$ C, $150 \mathrm{~cm}$ $2400 \pm 120$ $450 \mathrm{BC}$

Samples coll and subm 1974 by $\mathrm{H}$ W Scharpenseel and K Kirschey, Ordinariat f Bodenkunde, Hamburg Univ. Comment: in general, samples from Cap Bon and transition to Sahel (HAM-157-165) show fA-horizons of ca $1300 \mathrm{yr}$ (Islamic conquest?) $2300 \mathrm{yr}$ (deforestation and alluviation due to Punic civilization?), and $4500 \mathrm{yr}$ (by higher fossil horizons rejuvenated fossil soil from period of climatic optimum?). Medjerdah- and Bou Huertma R show fossil horizons from 5000 to $6000 \mathrm{yr}$ and 7000 to $8000 \mathrm{yr}$; younger samples from drainage ditches are probably rejuvenated by roots or disturbed.

Soil profile of Sol Brun a Croûte with calcareous crust
HAM-175. Soil profile with free limestone and faintly developed calcareous crust,
$10,820 \pm 170$
$8870 \mathrm{BC}$ 0 to $15 \mathrm{~cm}\left(36^{\circ} 23.5^{\prime} \mathrm{N}, 10^{\circ} 33^{\prime} \mathrm{E}\right)$

HAM-176. Same profile, 15 to $120 \mathrm{~cm}$

$23,560 \pm 500$

$21,610 \mathrm{BC}$

HAM-177. Same profile, 120 to $130 \mathrm{~cm}$

$25,900 \pm 840$

$23,950 \mathrm{BC}$ 
HAM-178. Same profile, 130 to $160 \mathrm{~cm}$

$21,500 \pm 410$

$19,550 \mathrm{BC}$

HAM-179. Same profile, 160 to $170 \mathrm{~cm}$

$27,160 \pm 1090$

$25,210 \mathrm{BC}$

HAM-180. Same profile, 170 to $190 \mathrm{~cm}$

$12,590 \pm 160$

$10,640 \mathrm{BC}$

HAM-181. Same profile, 190 to $200 \mathrm{~cm}$

$25,270 \pm 610$

23,320 BC

HAM-182. Same profile, 200 to $250 \mathrm{~cm}$

$19,230 \pm 780$

$17,280 \mathrm{BC}$

Samples coll and subm 1974 by C Haupenthal, Hessisches Landesamt f Bodenforschung, Wiesbaden. Comment: ca 25,000 yr old, at the most $20,000 \mathrm{yr}$, when subtracting $50 \%$ lithic dead carbon contribution, age of faintly developed calcareous crust appears rather low. Dated for orientation, rather than for convincing evidence HAM-180 must be rejuvenated or contaminated for reasons unknown to the analyst.

\section{SUBHYDRIC SOIL SAMPLES}

Subhydric soil samples of artificial lake of Ruhr R

HAM-183. Baldeney Lake Essen-Werden, S shore, ca $800 \mathrm{~m}$ E Villa Hügel, 0 to $20 \mathrm{~cm}$

$$
\begin{aligned}
& 8480 \pm 110 \\
& 6530 \mathrm{BC} \\
& 12,160 \pm 270 \\
& 10,210 \mathrm{BC} \\
& 9950 \pm 130 \\
& 8000 \mathrm{BC} \\
& 9720 \pm 130 \\
& 7770 \mathrm{BC} \\
& 6180 \pm 210 \\
& 4230 \mathrm{BC} \\
& 7390 \pm 170 \\
& 5440 \mathrm{BC}
\end{aligned}
$$

HAM-184. Same location, ca 400m E Villa Hügel, 0 to $25 \mathrm{~cm}$

HAM-185. Approx opposite Villa Hügel, 0 to $35 \mathrm{~cm}$

HAM-186. Ca 200m W Villa Hügel, 0 to $35 \mathrm{~cm}$

HAM-187. In front of large boating port, $\mathrm{S}$ shore E of HAM-183, 0 to $35 \mathrm{~cm}$

HAM-188. Ca 200m E of boating port, E of HAM-183 and 187.

Samples coll and subm by $\mathrm{H}$ W Scharpenseel and D Schroeder, Inst f Bodenkunde, Bonn Univ. Comment: old ages of organic matter from young man-made lake was surprising. Investigation revealed that Ruhr $\mathrm{R}$ transports coal dust particles through lake bed. Old ages result of fossil carbon contamination.

\section{OTHER SAMPLES}

HAM-189. Clay pit Kaerlich, wood from tree, underlying Alleröd and Holocene soil $\left(50^{\circ} 23^{\prime} \mathrm{N}, 7^{\circ} 28^{\prime} \mathrm{E}\right)$

$29,600 \pm 1150$ 27,650 вс

Sample coll and subm 1973 by J Frechen, Min Inst, Bonn Univ. Comment: sample apparently is derived from Paudorf interstadial. 
HAM-190. Grass, Röttgen, near Bonn, Oct 1973

$\left(50^{\circ} 41^{\prime} \mathrm{N}, 7^{\circ} 5.5^{\prime} \mathrm{E}\right)$

$132.9 \pm 0.5 \%$

HAM-191. Grass, same spot, Sept 1974

$138.5 \%$ modern

Samples coll and subm by $\mathrm{H}$ W Scharpenseel as follow-up of yearly samples since 1957. Comment: dates in general show decreasing trend of thermonuclear bomb carbon ( $\mathrm{R}, 1968, \mathrm{v} 10, \mathrm{p} 24-27$; R, 1969, v 11 , p 10-13; R, 1970, v 12, p 38; R, 1971, v 13, p 212; R, 1972, v 15, p 40).

\section{ARCHAEOLOGIC SAMPLES}

Iversheim, Rhineland

Charcoal and recarbonified limestone from oven remains of Roman lime furnace

HAM-192. Dry charcoal from lime furnace of Roman origin, estimated age: 1 st to 2nd century AD $\left(50^{\circ} 35^{\prime} \mathrm{N}, 06^{\circ} 46^{\prime} \mathrm{E}\right)$

$1740 \pm 70$ AD 210

HAM-193. Charcoal, same sample loc, on upper burning level, age estimate: AD 260 to 300

$1640 \pm 70$ AD 310

HAM-194. Charcoal, same sample loc, on lower burning level, age estimate somewhat $1820 \pm 70$ older than HAM-193

HAM-195. Presumably recarbonized lime in burned dolomite fitting of oven, upper region, expected age similar to HAM-193

HAM-196. Presumably recarbonized lime in burned dolomite fitting of oven, $140 \mathrm{~cm}$ deeper than preceding sample, AD 580 expected age similar to HAM-193

Samples coll and subm 1973 by B Sölter, Rheinisches Landesmus, Bonn. First dug-out lime burning oven of Roman origin. Comment: charcoal dates are close to expected ages. Recarbonized lime is obviously contaminated by bomb carbon, especially surface near HAM-195.

\section{Au, Hallertau, Freising Co, Bavaria}

Charcoal in prehistoric soil relics, dating early settlements. Archaeologic dates of line-band-ceramics and linear-band-ceramics indicate 3000 or 4000 yr BC.

HAM-197. Charcoal Hallertau $\left(48^{\circ} 33^{\prime} \mathrm{N}, 11^{\circ} 45^{\prime} \mathrm{E}\right) \quad \begin{aligned} & 5990 \pm 90 \\ & \text { BС }\end{aligned}$

Sample coll and subm 1974 by U Schwertmann, Inst Soil Sci, Tech Univ Munich. Comment: date is expected.

\section{Bulgaria}

Wood and charcoal samples; mining relics 
HAM-198. Part of wooden trough in old PB-Zn mine pit, Straschimir-Rhodopen region, $\left(41^{\circ} 22^{\prime} \mathrm{N}, 25^{\circ} 00^{\prime} \mathrm{E}\right)$

HAM-199. Part of wooden trough in old mine pit, Bakadjik, $30 \mathrm{~km} \mathrm{~S} \mathrm{Jambol,}$ $\left(42^{\circ} 24^{\prime} \mathrm{N}, 26^{\circ} 46^{\prime} \mathrm{E}\right)$

HAM-200. Part of wooden mine support, Tscherweno Sname copper mine, $\mathrm{S}$ Burgas, $\left(42^{\circ} 24^{\prime} \mathrm{N}, 27^{\circ} 38^{\prime} \mathrm{E}\right)$

$$
1560 \pm 120
$$
AD 390

$1790 \pm 70$ AD 160

$$
\begin{gathered}
2710 \pm 70 \\
760 \mathrm{BC}
\end{gathered}
$$

HAM-201. Part of wooden mine support, Bakadjik mine, $30 \mathrm{~km} \mathrm{~S} \mathrm{Jambol,}$ $\left(42^{\circ} 24^{\prime} \mathrm{N}, 26^{\circ} 46^{\prime} \mathrm{E}\right)$

$$
\begin{gathered}
1940 \pm 60 \\
\text { AD } 10 \\
\\
1650 \pm 60 \\
\text { AD } 300 \\
2510 \pm 80 \\
560 \mathrm{BC}
\end{gathered}
$$

HAM-202. Wooden double piston pump, Jambol, $\left(42^{\circ} 24^{\prime} \mathrm{N}, 26^{\circ} 46^{\prime} \mathrm{E}\right)$

HAM-203. Charcoal of old copper mine, Tscherweno Sname, $S$ Burgas, $\left(42^{\circ} 24^{\prime} \mathrm{N}, 27^{\circ} 38^{\prime} \mathrm{E}\right)$

Samples coll and subm 1974 by E Maximoff and G Weisgerber, Bergbau Mus Bochum. Comment: most samples date to Roman time, except wood and charcoal samples from copper mine, Tscherweno Sname, which are older, even if older mature wood was used for production of supports and for charcoal producing fuel.

Wood from gold, silver, and copper-lead mines

HAM-204. Round wooden climbing pole of old gold mine, Jaworow Preslap near Goweschda $\left(43^{\circ} 23^{\prime} \mathrm{N}, 22^{\circ} 56^{\prime} \mathrm{E}\right)$

$$
\begin{array}{r}
1750 \pm 60 \\
\text { AD } 200
\end{array}
$$

HAM-205. Slightly burned wood from copper mine, Plakalnitza near Vratza $\left(43^{\circ} 4^{\prime} \mathrm{N}, 23^{\circ} 30^{\prime} \mathrm{E}\right)$

HAM-206. Part of large wooden trough, silver-lead mine Tschiprowtzi $\left(43^{\circ} 4^{\prime} \mathrm{N}, 23^{\circ} 30^{\prime} \mathrm{E}\right)$

AD 1430 $1730 \pm 50$ AD 220

$520 \pm 60$

Samples coll and subm 1974 by E Maximoff and G Weisgerber, Bergbau Mus, Bochum. Comment: HAM-204-205 date to Roman time; HAM206 suggests medieval origin.

\section{Israel}

Charcoal from Timna mine $\left(29^{\circ} 40^{\prime} \mathrm{N}, 34^{\circ} 50^{\prime} \mathrm{E}\right)$

HAM-207. Charcoal, Mine 212/1, Timna, S-Israel, site in Egyptian tunnel
$2910 \pm 70$

960 вС 
HAM-208. Charcoal, Mine 212/1, Egyptian tunnel

HAM-209. Charcoal, Mine 212/1, Egyptian tunnel sample too small, discarded

960 вС

HAM-210. Charcoal, Mine 212/le, Egyptian tunnel

$3050 \pm 70$

$1100 \mathrm{BC}$

HAM-211. Charcoal, Mine 212/lg, Egyptian tunnel

$2640 \pm 60$

$690 \mathrm{BC}$

HAM-212. Charcoal, Mine 212/2, Egyptian tunnel

$2780 \pm 90$

$830 \mathrm{BC}$

HAM-213. Charcoal, Mine 212/2, Egyptian tunnel

$3890 \pm 70$

1940 вC

HAM-214. Charcoal, Mine 212/2a, Egyptian tunnel

$4000 \pm 90$ $2050 \mathrm{BC}$

HAM-215. Charcoal, mining site, slag pile (Cut 25, Layer 2)

$4020 \pm 100$ $2070 \mathrm{BC}$

HAM-216. Charcoal, mining site, slag pile, Timna 30, Layer 1

$3340 \pm 60$

$1390 \mathrm{BC}$

HAM-217. Charcoal, mining site, slag pile, Timna 30, Layer 1, sample too small, discarded.

Samples coll and subm 1974 by G Weisgerber, Bergbaumus Bochum. Comment: HAM-207-212 agree with estimated age ca $3000 \mathrm{yr}$, based on assumed origin at King Solomon's time. HAM-213-216 are unexplainably older.

\section{Iran}

Wood samples of ruin at $\mathrm{E}$ rim of oasis Shahdad, Central Iran

HAM-218. Wooden lintel "Imamzadeh" $\left(30^{\circ} 25^{\prime} \mathrm{N}, 57^{\circ} 45^{\prime} \mathrm{E}\right)$

AD 1520

HAM-219. Wooden lintel, SE side base floor, apparently palm wood, $\left(30^{\circ} 25^{\prime} \mathrm{N}, 57^{\circ} 45^{\prime} \mathrm{E}\right)$

$1150 \pm 110$ AD 800

HAM-220. Wooden window lintel, E apse, same loc $430 \pm 70$ AD 1520

Samples coll and subm 1973 by U W Hallier, Inst Bot, Düsseldorf Univ. Comment: expectation, that ruins might be relics of Nesturian church building, could be confirmed by HAM-219. The other samples seem rather young. 
Organic matter and wood samples, Khorasaner Kavir, Central Iran and border region along Afghanistan.

HAM-221. Organic matter/charcoal in preIslamic pottery. SE rim of Tar-o-Sar, Nimrouz $\left(30^{\circ} 33^{\prime} \mathrm{N}, 62^{\circ} 6^{\prime} \mathrm{E}\right)$

HAM-222. Wooden pole of doorway, Fort Nakhlak, N Kuh-i-Nakhlak $\left(33^{\circ} 12^{\prime} \mathrm{N}, 53^{\circ} 46^{\prime} \mathrm{E}\right)$

$$
2280 \pm 300
$$

$300 \mathrm{BC}$

$$
1430 \pm 60
$$$$
\text { AD } 520
$$

HAM-223. Wooden pole of door construction, Fort Nakhlak N Kuh-i-Nakhlak $\left(33^{\circ} 12^{\prime} \mathrm{N}, 53^{\circ} 46^{\prime} \mathrm{E}\right)$

HAM-224. Construction wood of water tank, Qual'eh Dukhtar near Duruna $\left(35^{\circ} 17^{\prime} \mathrm{N}, 57^{\circ} 13^{\prime} \mathrm{E}\right)$

$$
1490 \pm 60
$$
AD 460

$$
1030 \pm 80
$$
AD 920

Samples coll and subm by U W Hallier, Inst Bot, Düsseldorf Univ. Comment: HAM-221 agrees well with town Tar-o-Sar's settlement history. HAM-222-224 relate to former samples BONN-1666-1668 (R, 1973, v 15, $\mathrm{p}$ 278). Confirmation is needed, if samples are derived from Parther or Sasanide times. Samples are younger than BONN-1668, and just exceed age ca 1300 yr. HAM-224 dates hitherto unknown and archaeologically undescribed ruins.

\section{Ecuador} $\left.18^{\prime} \mathrm{E}\right)$.

Bone, charcoal, and wood, Cochasqui, $70 \mathrm{~km} \mathrm{~N}$ Quito $\left(0^{\circ} 6^{\prime} \mathrm{N}, 78^{\circ}\right.$

HAM-225. Bones in deeper part of trench, pyramid N highland, (rather small $1930 \pm 70$ sample of collagen carbon)

HAM-226. Bones on top of burned plate, E $118.3 \pm 0.4 \%$ pyramid, 1 to $3 \mathrm{~m}$ (bones highly mineralized, very small sample, date to be discarded)

HAM-227. Wood and earth, pyramid, Cut 28,80 to $120 \mathrm{~cm}$

$$
\begin{gathered}
1020 \pm 120 \\
\text { AD } 930 \\
890 \pm 70 \\
\text { AD } 1060 \\
980 \pm 70 \\
\text { AD } 970 \\
910 \pm 60 \\
\text { AD } 1040
\end{gathered}
$$

HAM-230. Charcoal, planum 1, SE part, 3 to $5 \mathrm{~m}$

Samples coll and subm 1973 by $\mathrm{H}$ J Wentscher, Sem Anthropol, Rheinisches Landesmus Bonn. Comment: bone samples were highly mineralized, small samples questionable. Other dates agree well with estimated age, ca 1000 yr. 


\section{REFERENCES}

Diez, T, 1968, Die würm- und postwürmglazialen Terrassen des Lech und ihre Bodenbildungen: Eiszeitalter u Gegenwart, v 19, p 102-128.

Hofmann, B, 1966, Erläuterungen zur Bodenkarte von Bayern 1:25000, Blatt Landshut Ost: Bayrisches Geol Landesamt, München.

Ivanov, J V, 1974, Soils of Povolyhye: 10th internatl cong soil sci, Moscou-Wolga-Don excursion guide book.

Mückenhausen, E, Scharpenseel, H W, and Pietig, F, 1968, Zum Alter des Plaggeneschs: Eiszeitalter u Gegenwart, v 19, p 190-196.

Rückert, G, 1975, Die Böden des Nördlinger Ries: Mitt Deutschen Bodenkundlichen Gesellschaft, (Papers of Regensburg Conf, in press).

Scharpenseel, H W and Pictig, F, 1969, Einfache Boden- und Wasserdatierung durch Messung der ${ }^{14} \mathrm{C}$ - oder Tritium- konzentration: Geoderma, v 2, p 273-289.

1970, Altersbestimmung mit dem Flüssigkeits-Szintillations-Spektrometer Vereinfachte Benzolsynthese, auch aus kleinen $\mathrm{CO}_{2}$-Mengen: Atompraxis, $\mathrm{v} 16$, p 1-2.

Scharpenseel, H W, 1972, Messung der natürlichen C-14 Konzentration in der organischen Substanz von rezenten Böden, Eine Zwischenbilanz: Zeitschr Pflanzenernähr, Bodenkunde v 133, p 241-263.

Scharpenseel, H W and Pietig, F, 1970, University of Bonn natural radiocarbon measurements III: R, v 12, p 19-39. p 189-212. 1971, University of Bonn natural radiocarbon measurements IV: R, v 13 p $13-41$.

973, University of Bonn natural radiocarbon measurements V: R, v 15 P $1352-197$ p 252-279 radiocarbon measurements $I$ : $R, v 10, p$ 8-28.

- 1969, University of Bonn natural radiocarbon measurements II: R, v 11, p 3-14.

Schmidt-Kaler, H and Treibs, W, 1970, Exkursionsführer zur geologischen Übersichtskarte des Rieses, 1:100,000: Bayrisches Geol Landesamt, Munich. 